\title{
Pengembangan Antena Mikrostrip Susun untuk Radar Pengawas Pantai
}

\author{
Microstrip Antenna Array for Coastal Surveillance Radar \\ Fitri Yuli Zulkifli ${ }^{\text {a, }}$, Yuyu Wahyu ${ }^{\text {b }}$ Basari ${ }^{a}$, dan Eko Tjipto Rahardjo ${ }^{a}$ \\ ${ }^{a}$ Antenna Propagation and Microwave Research Group (AMRG) \\ Departemen Teknik Elektro, Fakultas Teknik, Universitas Indonesia \\ Depok 16424, Indonesia \\ ${ }^{b}$ Pusat Penelitian Elektronika dan Telekomunikasi, Lembaga Ilmu Pengetahuan Indonesia. \\ Komp LIPI Gd 20, Jl Sangkuriang 21/54D, Bandung 40135, Indonesia
}

\begin{abstract}
Abstrak
Makalah ini membahas pengembangan antena mikrostrip yang disusun secara linier sebanyak empat elemen untuk aplikasi radar pengawas pantai. Teknik pencatuan yang digunakan untuk mencatu antena susun ini adalah proximity coupled. Desain antena menggunakan software CST microwave studio dan dirancang untuk bekerja di frekuensi 9,4 GHz. Hasil simulasi memperlihatkan impedance bandwidth antena pada return loss $\leq-9,54 \mathrm{~dB}$ adalah $760 \mathrm{MHz}$ dari $9,34-10,1 \mathrm{GHz}$ dan dari hasil ukur adalah $860 \mathrm{MHz}$ dari frekuensi 9,35-10,21 GHz. Di samping itu, hasil simulasi menunjukkan half power beamwidth $(H P B W)$ pada phi=0 sebesar $23,7^{\circ}$ dengan sidelobe level $(S L L)$ sebesar $-12,03 \mathrm{~dB}$, sementara pada phi=90 diperoleh HPBW sebesar 77, $2^{\circ}$ dengan SLL tertekan sampai $-19,78 \mathrm{~dB}$. Sebagai tambahan, gain dari antena diperoleh sebesar 11,33 dB. Adapun hasil pengukuran menunjukkan hasil HPBW pada phi $=0$ sebesar $20^{\circ}$ dengan SLL sebesar $-18,9 \mathrm{~dB}$ dan pada phi=90 diperoleh HPBW sebesar $65^{\circ}$ dengan SLL -15,51 dB.
\end{abstract}

Kata kunci: antena susun, antena mikrostrip, radar pengawas pantai, proximity couple.

\section{Abstract}

This paper discusses a microstrip antenna linier array with four elements for Coastal Surveillance Radar. The feeding technique used for this antenna is proximity coupled feed technique. The software used for the antenna design is CST microwave studio software and the antenna is designed to work at frequency $9.4 \mathrm{GHz}$. Simulation result shows impedance bandwidth at return loss of $\leq-9,54 \mathrm{~dB}$ is $760 \mathrm{MHz}$ from $9,34-10,1 \mathrm{GHz}$ and the measurement results is $860 \mathrm{MHz}$ from 9,35-10,21 GHz. Moreover, simulation results of the half power beamwidth $(H P B W)$ at phi=0 is 23, $7^{\circ}$ with sidelobe level (SLL) of $-12.03 \mathrm{~dB}$, while at phi $=90$ the $H P B W$ is $77,2^{\circ}$ with $S L L$ of $-19.78 \mathrm{~dB}$. In addition, the antenna gain obatained is $11.33 \mathrm{~dB}$. While measurement result shows $H P B W$ at phi $=0$ is $20^{\circ}$ with SLL of $-18.9 \mathrm{~dB}$ and at phi $=90$ the HPBW is $65^{\circ}$ with SLL of $-15.51 \mathrm{~dB}$.

Keywords: microstrip antenna, array, coastal surveillance radar, proximity couple.

\section{PENDAhuluan}

Negara kesatuan republik Indonesia (NKRI) yang terdiri dari lebih 17.000 pulau dengan 2/3 wilayah terdiri dari lautan memerlukan pengamanan dan pengawasan wilayah dengan jumlah aparat dan peralatan yang sangat banyak. Pada kenyataannya, kemampuan TNI-AL dan POLRI untuk mengawasi wilayah RI sangat terbatas sehingga wilayah perairan Indonesia rawan akan pencurian ikan, pelanggaran wilayah oleh kapal-kapal asing, pembajakan kapal laut dan penyelundupan.

Salah satu cara untuk mengawasi pergerakan kapal laut sehingga dapat dicegah tindakan-tindakan yang dapat merugikan NKRI dan juga tabrakan kapal apabila hendak merapat ke pelabuhan adalah dengan menggunakan radar pengawas pantai (coastal surveillance radar (CSR)).

\footnotetext{
* Corresponding Author.

Email: yuli@eng.ui.ac.id

Received: November 18, 2013; Revised: Desember 2, 2013

Accepted: Desember 23, 2013

Published: Desember 30, 2013

(c) 2013 PPET - LIPI

doi : 10.14203/jet.v13.55-59
}

Dalam rangka memenuhi kebutuhan akan Radar untuk Indonesia, maka terjalinlah kolaborasi antara PPET-LIPI, UI, IRCTR-TU Delft dan institusi lainnya dalam pembuatan radar pertama buatan Indonesia yang dinamakan dengan INDRA (Indonesian Radar) [1] dan ISRA (Indonesian Surveillance Radar) [2].

Antena yang telah didesain untuk ISRA telah berkembang dan ada yang berupa antena mikrostrip [1], [3] dan ada juga antena yang berupa waveguide slot [4]. Antena mikrostrip pada [1] dan [3] dicatu secara langsung dengan saluran pencatu di bidang yang sama dengan patch antena sehingga ini dapat mempengaruhi unjuk kerja dari antena. Sidelobe level pada [3] juga masih sebesar 9,7 dB. Nilai ini masih terlalu besar untuk antena radar pantai yang memerlukan sidelobe level di bawah $13 \mathrm{~dB}$. Di samping itu, antena ISRA mempunyai spesifikasi impedance bandwidth sebesar $60 \mathrm{MHz}$ yaitu dari frekuensi $9,37 \mathrm{GHz}$ sampai $9,43 \mathrm{GHz}$ dengan frekuensi tengah di 9,4 GHz. Gain antena ISRA diharapkan lebih besar dari $25 \mathrm{~dB}$ dengan pola radiasi pada phi $=0$ (vertical beamwidth $)<30^{\circ}$ dan pada phi $=90$ (horizontal beamwidth) $<1^{\circ}$.

Pada makalah ini akan dibahas pengembangan antena susun linier mikrostrip empat elemen untuk radar 
pengawas pantai yang bekerja pada frekuensi $9,4 \mathrm{GHz}$ atau di $X$-band.

\section{SISTEM RADAR}

Radar merupakan akronim dari radio detection and ranging. Sistem radar merupakan sistem yang kompleks yang diperlihatkan pada Gambar 1.

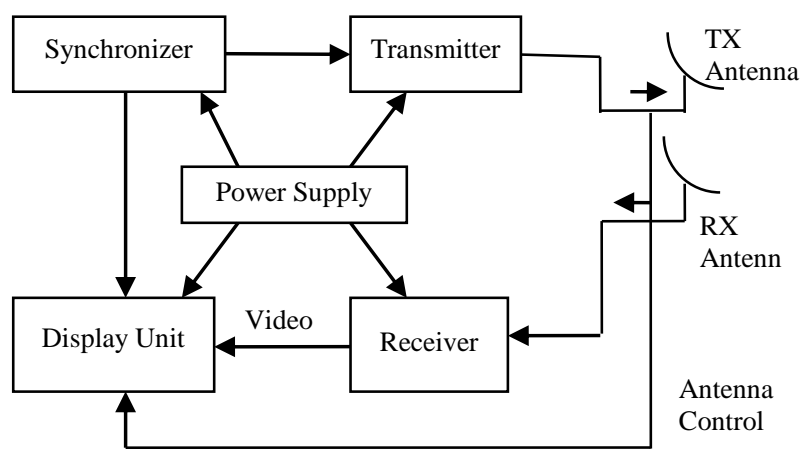

Gambar 1. Blok Diagram Sistem Radar [5].

Sistem radar akan mendeteksi obyek diawali dari bagian antena. Antena merupakan komponen yang krusial dalam sistem radar karena dapat menentukan unjuk kerja sistem radar keseluruhan yaitu untuk mendeteksi suatu objek.

Dari antena, data yang terdeteksi akan diolah dan ditampilkan oleh unit peraga/display unit. Unit peraga ini yang mengolah sinyal yang diterima dari bagian penerima menjadi suatu gambar yang dapat diinterpretasikan dengan mudah oleh pengguna.

Oleh karena itu bila kemampuan deteksi radar semakin canggih yang berarti didukung dengan kemampuan antena yang canggih juga, maka pemrosesan sinyal dari sinyal yang diterima oleh antena penerima menjadi tidak susah lagi.

Untuk aplikasi radar pengawas pantai yang dikembangkan ini, memiliki spesifikasi antena dengan frekuensi kerja 9,4 GHz, impedance bandwidth 60 MHz. Pola radiasi pada phi $=0$ lebih kecil dari $30^{\circ}$ dan pada phi=90 lebih kecil dari $1^{\circ}$ dengan SLL lebih kecil dari $-13 \mathrm{~dB}$. Gain antena yang diinginkan lebih besar dari $25 \mathrm{~dB}$ [2].

\section{DESAIN ANTENA 4 ELEMEN}

Sebelum mendesain antena empat elemen, terlebih dahulu di desain antena satu elemen berupa patch persegipanjang dengan teknik pencatuan proximity couple. Desain antena mikrostrip dilakukan pada bahan substrat Roger 5880 dengan konstanta dielektrik 2,2, tangential loss 0,0009, dan ketebalan substrat 1,575 $\mathrm{mm}$ yang diperlihatkan pada Gambar 2. Untuk memperoleh desain antena satu elemen ini menggunakan formula dari buku Balanis [6].

Gambar 2 memperlihatkan bahwa antena terdiri dari dua lapisan substrat. Lapisan pertama bagian atas berupa satu elemen antena berbentuk persegi panjang dan pada lapisan kedua substrat bagian atas merupakan mikrostrip line sebagai pencatu antena. Kedua lapisan substrat ini ditumpuk untuk menghasilkan antena satu elemen bentuk persegi panjang dengan teknik pencatuan proximity coupling.

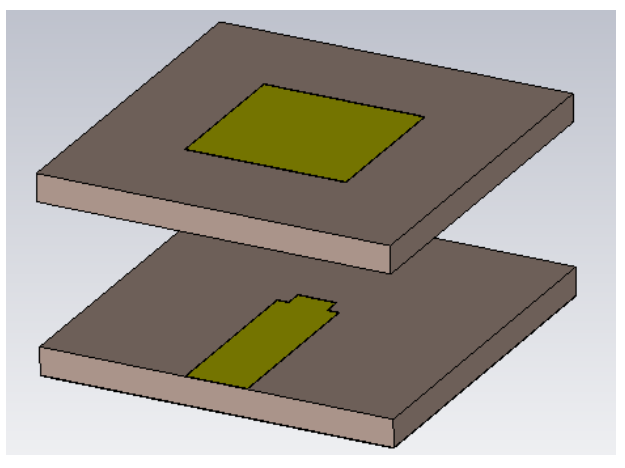

Gambar 2. Desain Antena Mikrostrip Satu Elemen Tampak Atas Secara Tiga Dimensi.

Hasil simulasi dari antena satu elemen ini diperlihatkan pada Gambar 3.

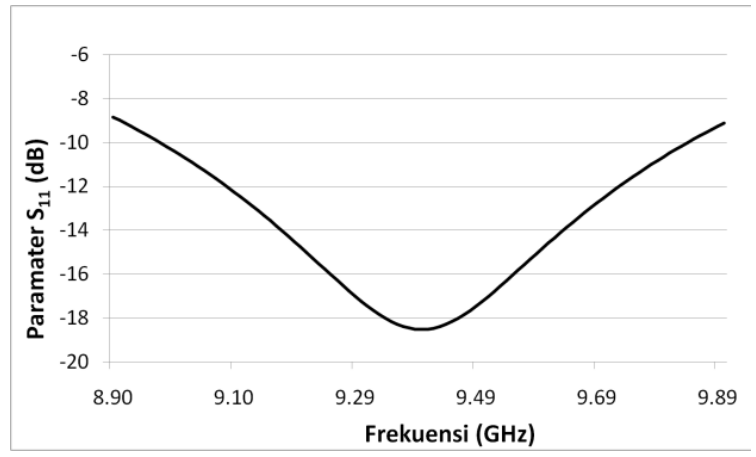

(a)

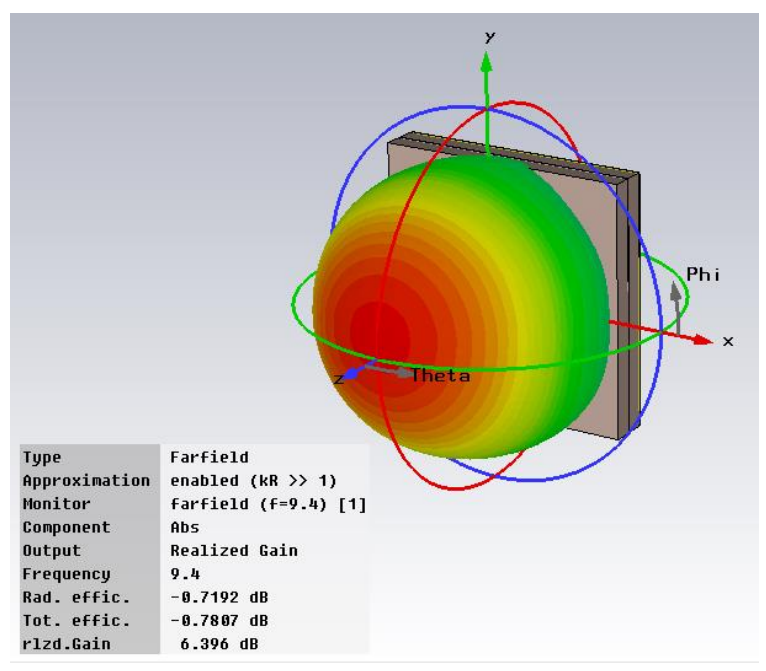

(b)

Gambar 3. Hasil Simulasi Satu Elemen, (a) Parameter $\mathrm{S}_{11}$, (b) Pola radiasi 3-D.

Gambar 3 (a) memperlihatkan hasil simulasi parameter $S_{11}$ yang menunjukkan frekuensi kerja dari antena. Pada nilai $\mathrm{S}_{11} \leq-14 \mathrm{~dB}$, maka diperoleh bandwidth antena selebar $450 \mathrm{MHz}$ yaitu dari frekuensi 9,18 GHz sampai 9,63 GHz.

Adapun Gambar 3 (b) memperlihatkan hasil simulasi tiga dimensi dari pola radiasi antena satu elemen dengan patch antena menghadap ke arah sumbu Z. Di samping itu, Gambar 3 (b) juga memperlihatkan gain antena satu elemen diperoleh sebesar 6,3 dB.

Antena satu elemen ini kemudian dikembangkan menjadi 4 x 1 elemen yang disusun secara linier. Hal ini 
dilakukan untuk memperoleh pola radiasi phi=0 (vertical beamwidth) $<30^{\circ}$. Antena empat elemen ini diperlihatkan pada Gambar 4.

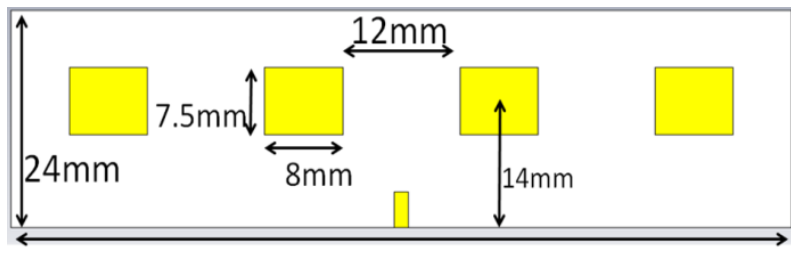

$80 \mathrm{~mm}$

(a)

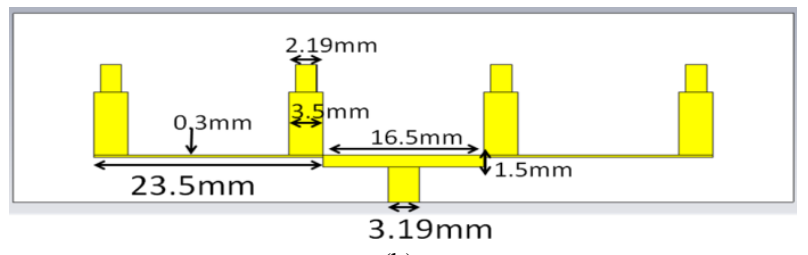

(b)

Gambar 4. Desain Antena Mikrostrip Empat Elemen Tampak Atas, (a) Lapisan Substrat 1, (b) Lapisan Substrat 2

Antena mikrostrip ini terdiri dari dua lapisan substrat. Lapisan pertama terdiri dari patch berbentuk persegi panjang sebanyak empat buah elemen yang disusun secara linier berupa 4 x 1 elemen seperti yang diperlihatkan pada Gambar 4 (a).

Lapisan kedua substrat, pada bagian atas didesain pencatuan antena berupa konfigurasi series feed unequal power divider yang akan mencatu antena secara proximity coupling. Desain ini diperlihatkan pada Gambar 4 (b). Pada bagian bawah lapisan substrat kedua terdapat bagian pentanahan dari antena susun tersebut.

Bagian yang berwarna kuning atau yang diarsir merupakan bahan konduktor dari substrat tersebut.

\section{IV.}

\section{HASIL DAN ANALISIS}

Pada bagian ini akan membahas hasil simulasi desain antena mikrostrip 4x1 elemen dengan hasil pengukuran. Gambar 5 memperlihatkan foto hasil pabrikasi dari antena mikrostrip 4x1 elemen.

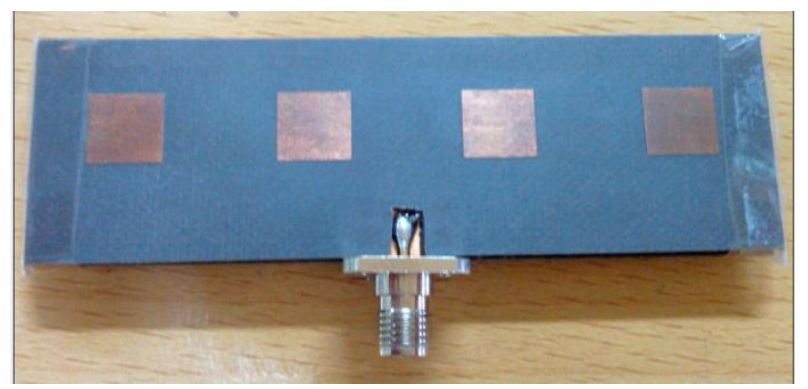

Gambar 5. Foto Antena Mikrostrip 4x1 Elemen Tampak Atas

Hasil pertama yang diukur adalah frekuensi kerja antena susun empat elemen tersebut yang diperlihatkan pada Gambar 6. Bila membandingkan hasil simulasi dan hasil pengukuran dari frekuensi kerja antena, maka diperoleh hasil yang serupa. Hasil simulasi memperlihatkan impedance bandwidth antena pada return loss $\leq-9,54 \mathrm{~dB}$ adalah $760 \mathrm{MHz}$ yaitu dari frekuensi 9,34 hingga $10,1 \mathrm{GHz}$ dan dari hasil pengukuran diperoleh bandwidth sebesar $860 \mathrm{MHz}$ yaitu di frekuensi 9,35 sampai 10,21 GHz.

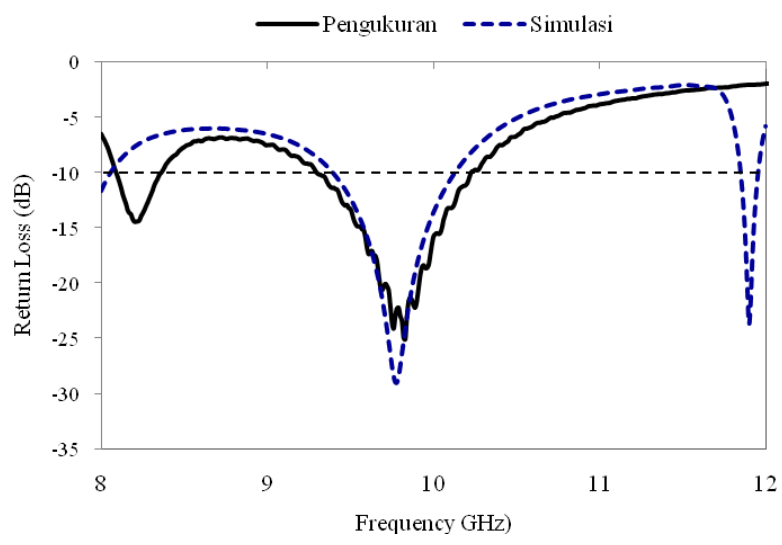

Gambar 6. Perbandingan Hasil Return Loss Antena.

Hasil pengembangan antena susun empat elemen ini menunjukkan gain antena sebesar $11,33 \mathrm{~dB}$ dengan pola radiasi tiga dimensi (3D) yang ditunjukkan pada Gambar 7.

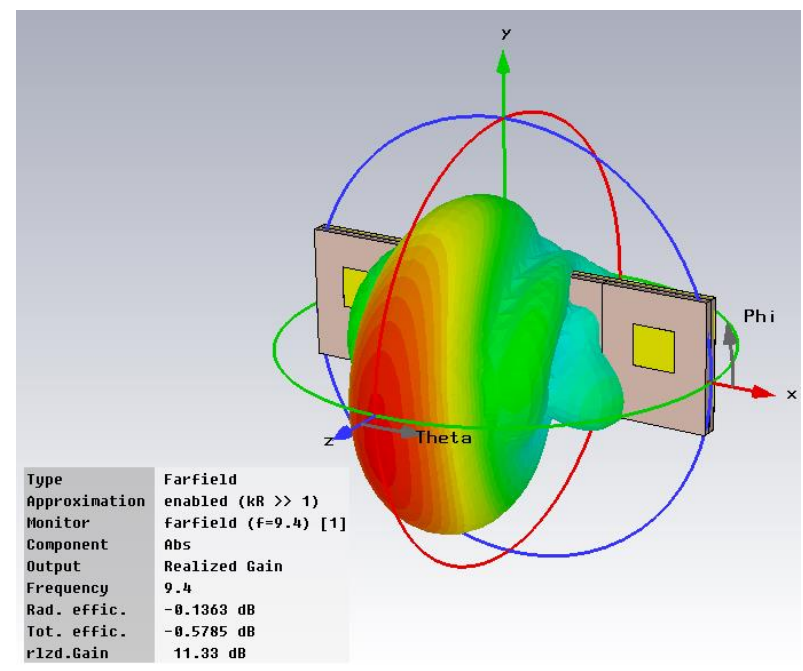

Gambar 7. Hasil Simulasi Polaradiasi 3D Antena dan Gain Antena.

Bila hasil pola radiasi tiga dimensi ini diplot dalam dua dimensi, maka hasil pola radiasi tersebut akan diperlihatkan pada phi=0 yang ditunjukkan pada Gambar 8 (a) dan phi=90 yang diperlihatkan pada Gambar 8 (b).

Hasil simulasi menunjukkan half power beamwidth (HPBW) pada phi $=0$ sebesar $23,7^{\circ}$ dengan sidelobe level (SLL) sebesar $-12,03 \mathrm{~dB}$, sementara pada phi=90 diperoleh HPBW sebesar $77,2^{\circ}$ dengan SLL tertekan sampai -19,78 dB.

Pengukuran pola radiasi antena dilakukan dalam ruang anti gema di laboratorium telekomunikasi Departemen Teknik Elektro, Fakultas Teknik, Universitas Indonesia. Gambar 8 (a) memperlihatkan HPBW pada phi $=0$ diperoleh sebesar $20^{\circ}$ dan di Gambar 8 (b) menunjukkan HPBW pada phi $=90$ sebesar $65^{\circ}$.

Hasil perbandingan pola radiasi antara hasil simulasi dengan hasil pengukuran memperlihatkan bentuk pola yang serupa. Pada hasil pengukuran phi $=0$ memperlihatkan sidelobe level sebesar -18,9 dB dan 
pada phi=90 memperlihatkan sidelobe level sebesar $-15,51 \mathrm{~dB}$.

Hasil desain antena $4 \times 1$ elemen ini telah memenuhi spesifikasi pola radiasi phi $=0$ (vertical beamwidth) $<$ $30^{\circ}$.

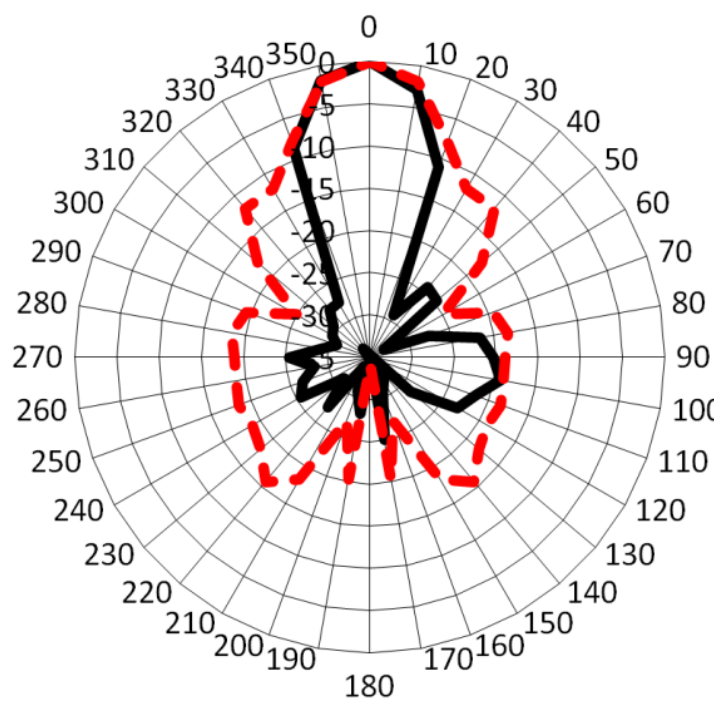

Pengukuran $\longrightarrow$-Simulasi

(a)

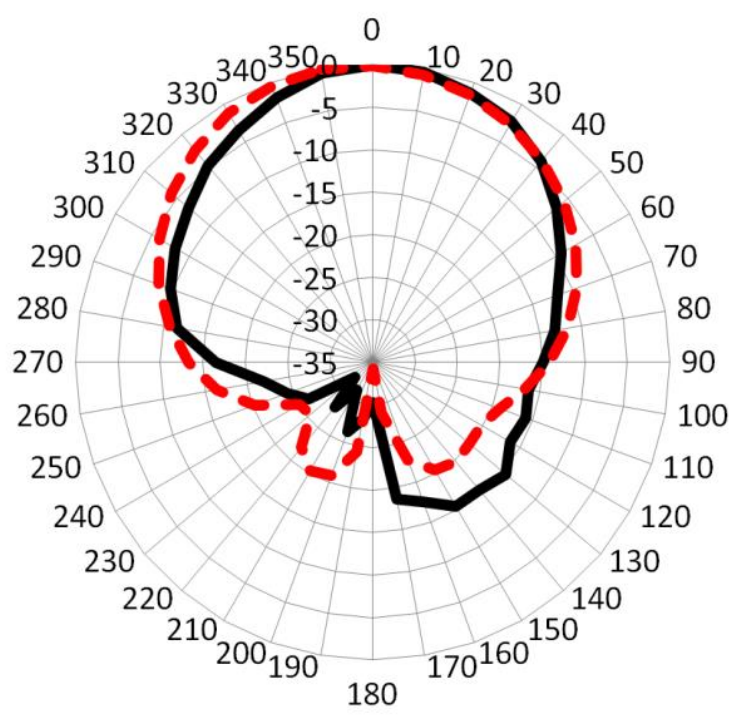

Pengukuran $\rightarrow$-Simulasi

(b)

Gambar 8. Perbandingan Pola Radiasi, (a) pada Phi=0, (b) pada $\mathrm{Phi}=90$

\section{DESAIN ANTENA 4X64 ELEMEN}

Hasil simulasi dan pengukuran dari antena empat elemen ini dikembangkan lagi untuk memenuhi standar spesifikasi antena radar pengawas pantai yang belum tercapai yaitu memperoleh gain antena ISRA lebih besar dari $25 \mathrm{~dB}$ dengan pola radiasi pada phi=90 (horizontal beamwidth) $<1^{\circ}$.

Untuk memperoleh spesifikasi ISRA khususnya gain antena dan pola radiasi pada phi $=90$, maka disimulasikan secara bertahap 4x32 elemen dan 4x48 elemen yang diperlihatkan pada Gambar 9.

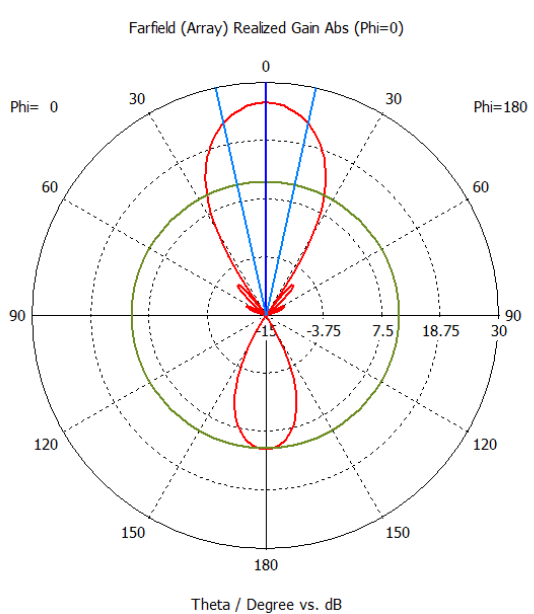

(a)

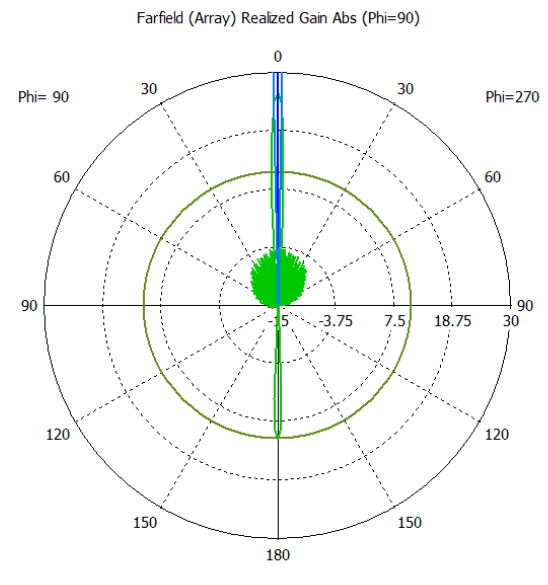

(b)
Main lobe magnitude $=26.0 \mathrm{~dB}$ Main lobe direction $=0.0$ deg. Angular width $(3 \mathrm{~dB})=24.6 \mathrm{deg}$ Side lobe level $=-15.1 \mathrm{~dB}$ requency $=9.4$ Main lobe magnitude $=26.0 \mathrm{~dB}$ Main lobe direction $=0.0 \mathrm{deg}$ Angular width $(3 \mathrm{~dB})=2.4 \mathrm{deg}$
Side lobe level $=-15.1 \mathrm{~dB}$

\section{Gambar 9. Hasil Simulasi Pola Radiasi 4x32 Elemen dan 4x48 Elemen, (a) pada $\mathrm{Phi}=0$, (b) pada $\mathrm{Phi}=90$}

Dari hasil simulasi baik 4x32 elemen maupun $4 \times 48$ elemen menunjukkan pada phi=90 diperoleh HPBW sebesar $2,4^{\circ}$ sehingga tidak berhasil diperoleh pola radiasi phi $=90$ (horizontal beamwidth) $<1^{\circ}$, oleh karena itu desain antena dikembangkan lagi menjadi 4x64 elemen.

Hasil simulasi antena 4x64 elemen diperlihatkan pada Gambar 10. Antena ini memiliki gain sebesar $29,51 \mathrm{~dB}$.

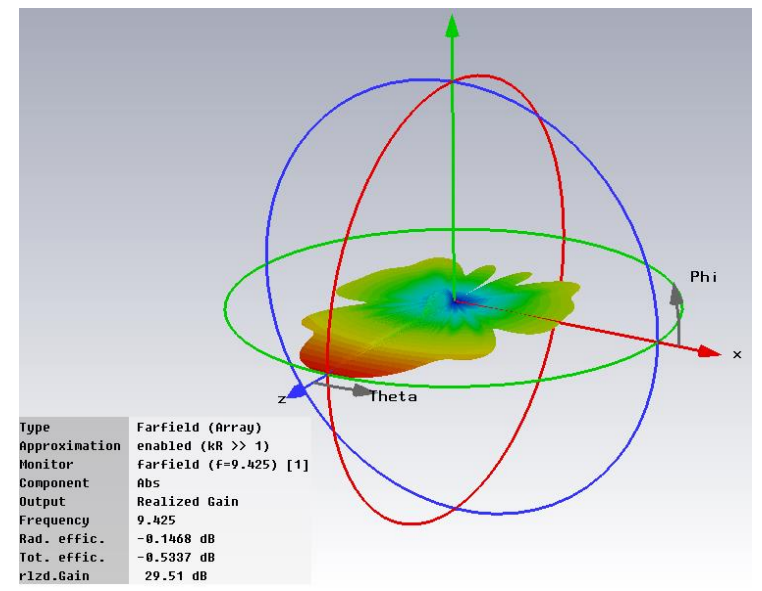

Gambar 10. Hasil Simulasi Pola radiasi 3D Antena dan Gain Antena 


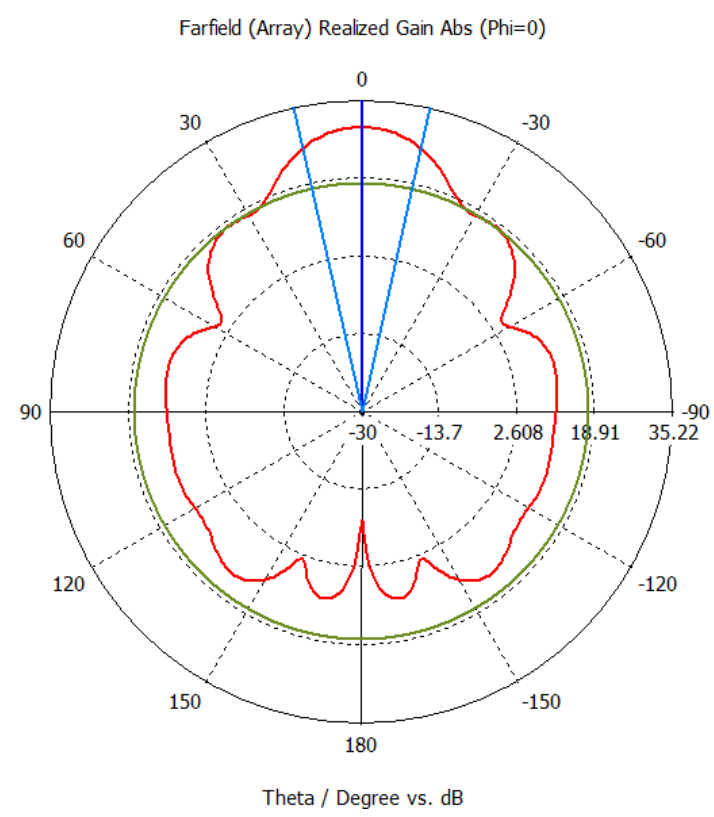

(a)

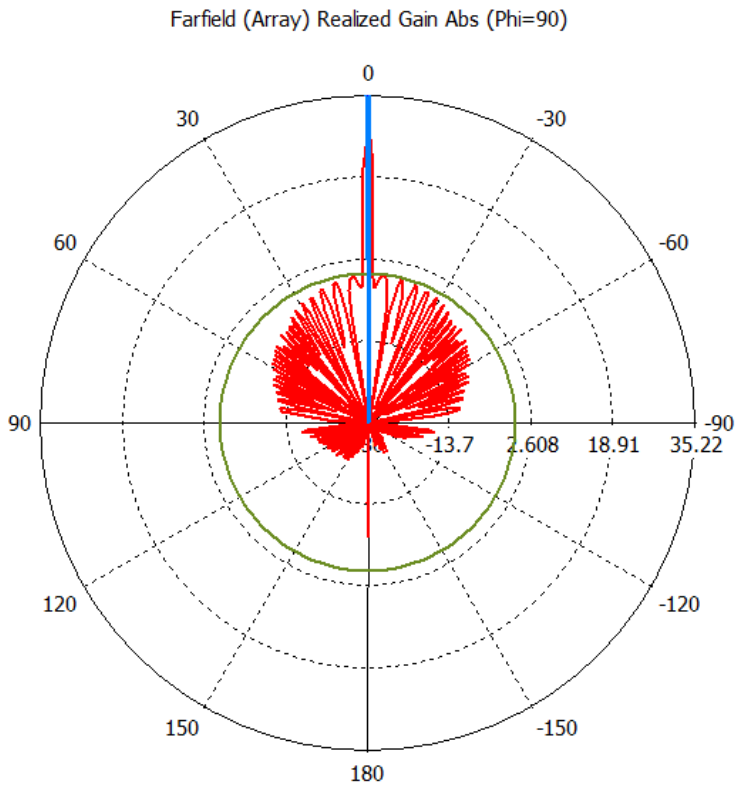

Theta / Dearee vs. dB

(b)

Gambar 11. Hasil Simulasi Pola Radiasi, (a) pada Phi=0 (b) pada $\mathrm{Phi}=90$

Hasil simulasi pola radiasi ini bila dilihat pada phi=0 yang ditunjukkan pada Gambar 11 (a), memperlihatkan hasil HPBW sebesar $25,1^{\circ}$ dengan SLL sebesar -11,7. Adapun pola radiasi antena pada phi $=90$ yang diperlihatkan pada Gambar 11 (b), menunjukkan bahwa diperoleh HPBW sebesar $0,7^{\circ}$ dengan SLL sebesar $-29,9 \mathrm{~dB}$.

Dari hasil simulasi ini, memperlihatkan bahwa untuk memenuhi spesifikasi antena radar pengawas pantai, maka diperlukan antena susun sebanyak 4x64 elemen.

\section{KESIMPULAN}

Desain antena mikrostrip 4x1 elemen dengan teknik pencatuan proximity coupling telah dilakukan, kemudian dipabrikasi, dilakukan pengukuran, dan hasilnya dianalisis. Hasil simulasi diperoleh bahwa antena dapat bekerja pada frekuensi $9,4 \mathrm{GHz}$ dan gain antena diperoleh sebesar $11,33 \mathrm{~dB}$. Pada phi=0 diperoleh HPBW sebesar sebesar $23,7^{\circ}$ dengan SLL= $-12,03 \mathrm{~dB}$. Sedangkan pada phi $=90$ diperoleh $\mathrm{HPBW}=77,2^{\circ}$ dengan SLL=-19,78 dB. Adapun hasil pengukuran menunjukkan hasil HPBW pada phi=0 sebesar $20^{\circ}$ dengan SLL sebesar $-18,9 \mathrm{~dB}$ dan pada phi=90 diperoleh HPBW sebesar $65^{\circ}$ dengan SLL= $-15,51 \mathrm{~dB}$.

Bila antena ini dikembangkan lagi menjadi 4x64 elemen, maka antena ini sudah dapat memenuhi spesifikasi antena radar pengawas pantai.

\section{UCAPAN TERIMA KASIH}

Penelitian ini terlaksana dengan sebagian pendanaan didanai oleh Hibah Kolaborasi Nasional Universitas Indonesia dengan nomor kontrak: 0690/H2.R12/HKP.05.00 Perjanjian/2013.

Penulis juga ingin mengucapkan terima kasih kepada Aditya Inzani Wahdiyat, Nugroho dan Dony Canisius Sirait yang telah membantu Penulis dari segi teknis.

\section{DAFTAR PUStaka}

[1] A. A. Lestari, P. Hakkaart, J.H. Zijderveld, F. V. D. Zwan, M Hajian, and L. P. Ligthart, "INDRA: the Indonesian maritime radar" in Proceedings of the 5th European Radar Conference, 2008.

[2] Mashury, "Building a radar from the scratch: ISRA LIPI radar experience", in Proceeding International Conference on Telecommunications (ICTel), Bandung, 2009.

[3] Y. Wahyu, Y. P. Saputera, and I. D. P. Hermida, "Array planar antenna using thick film on alumina substrate for X-band radar", in Proc. Of International Conference on Radar, Antenna, Microwave, Electronics and Telecommunications (ICRAMET), Surabaya, 2013.

[4] F. Y. Zulkifli, U. Ulya, E. T. Rahardjo, dan Y. Wahyu, "Pengembangan antena waveguide 8 slot untuk aplikasi radar pengawas pantai", Jurnal Elektronika dan Telekomunikasi, PPET-LIPI, vol.12, no.1, Januari-Juni 2012.

[5] B. Edge, RADAR Principles, Technology, Applications, Prentice Hall, Inc., 1993.

[6] R. Garg, P. Bhartia, I. Bahl, and A. Ittipiboon, Microstrip Design Handbook, Norwood, MA: Artech House Inc., 2001. 